\section{CarakaTanil \\ Journal of Sustainable Agriculture \\ ISSN 2613-9456 (Print) 2599-2570 (Online)}

\title{
The Correlation and Regression Analysis of The Growth and Physiological Parameters: How Paclobutrazol Increases Bulb Yield on Three Cultivars of True Shallot Seed
}

\author{
Prahesti Elizani and Endang Sulistyaningsih* \\ Department of Agronomy, Faculty of Agriculture, Universitas Gadjah Mada, Yogyakarta, Indonesia \\ *Corresponding author: endangsih@ugm.ac.id
}

\begin{abstract}
True Shallot Seed (TSS) is a planting material for shallots in the forms of seeds. It shows a visual appearance of the fresh green shoot even though in the harvest season. This condition indicates that TSS still has potential assimilates which should be optimized for bulbs formation. Paclobutrazol is increasing assimilate translocation from source to sink by activating the sucrose transporter enzyme and changing the phytohormones balance. The study aimed to find out how paclobutrazol increased bulb yield on TSS by analyzing the closeness in the relationship between and the influence of physiological property variables and growth analysis. The study was conducted at Universitas Gadjah Mada experimental field, Yogyakarta, from September to November 2017. It was arranged in a Randomized Complete Block Design with three replications. The first factor included the paclobutrazol concentration $(0,15,30$ and $45 \mathrm{mg} \mathrm{L}^{-1}$ ), while the second one included TSS cultivars (Tuk Tuk, Sanren and Lokananta). Correlation and regression were used in the data analysis. The results revealed that paclobutrazol significantly affected the physiological properties and the growth of TSS, instead of cultivars. Regression analysis showed that the effect of the concentration of the applied paclobutrazol formed quadratic pattern, where most observed variables had a positive correlation with shallot productivity. Paclobutrazol increased bulb yield by maintaining shoot biomass duration (SBD) and chlorophyll content which had a positive and linear effect on plant growth rate (PGR). The PGR might increase bulb yield per planting hole and indirectly increase its productivity. Paclobutrazol application at $15-30 \mathrm{mg} \mathrm{L}^{-1}$ could be used to improve bulb yield in TSS.
\end{abstract}

Keywords: growth retardant, productivity, shallots

Cite this as: Elizani, P., \& Sulistyaningsih, E. (2019). The Correlation and Regression Analysis of The Growth and Physiological Parameters: How Paclobutrazol Increases Bulb Yield on Three Cultivars of True Shallot Seed. Caraka Tani: Journal of Sustainable Agriculture, 34(2), 128-139. doi: http://dx.doi.org/10.20961/carakatani. v34i2.29148

\section{INTRODUCTION}

Shallot commodities with high economic value influence the rate of inflation. In Indonesia, shallots are cultivated intensively in 34 provinces with a total harvested area in 2017 of 158,172 ha with the total production of $1,470,154$ tons (the Central Bureau of Statistics (BPS, 2018). Several problems still hamper the development of cultivation in Indonesia. Those problems include the unavailability of seeds with good quality throughout the growing season and the presence of seed-borne pathogens. Shallot production using bulbs as the planting materials in the long term causes accumulation of pathogens (Widodo et al., 2011). The availability of bulbs is also limited since it depends on the planting seasons and requires a long storage time (maximum 6-8 months) until the bulbs are ready to be used as planting seeds (Pardjo et al., 2012). These problems can be solved by using True Shallot

\footnotetext{
* Received for publication April 8, 2019

Accepted after corrections May 24, 2019
} 
Seed (TSS) as an alternative substitution of the bulbs as the planting materials. TSS is known to have higher productivity, fewer seed needs, more efficient distribution and storage of seeds, the longer shelf life of seeds and higher resistance to viruses and seed infectious diseases (Pangestuti and Sulistyaningsih, 2011).

Such cultivars as Tuk Tuk, Sanren and Lokananta are superior shallots cultivars produced by the East West Seed Indonesia Ltd. They have been registered in the Ministry of Agriculture of the Republic of Indonesia with the numbers: 361/Kpts/SR.120/5/2006; 072/Kpts/ SR.120/D.2.7/7/2013; and 059/Kpts/SR.120/ D.2.7/6/2017. Tuk Tuk can adapt well in lowlands with an altitude of 20-220 m.a.s.l. and is very well planted in the dry season (the Ministry of Agriculture of the Republic of Indonesia, 2006). Sanren can be produced well when planted in the dry or rainy season. It has high productivity and requires the medium bulb size. In addition, it is resistant to leaf blight disease which often attacks during the rainy season, adapts well in lowlands with an altitude of 50-100 m.a.s.l (the Ministry of Agriculture of the Republic of Indonesia, 2013). Meanwhile, Lokananta has fusarium wilt resistance and high production and is suitable to be planted in lowlands (the Ministry of Agriculture of the Republic of Indonesia, 2017).

TSS has shoots that do not experience senescence even after entering the harvest season. This means that the shoots still have a high assimilate potential that is large enough to be translocated for bulb formation. Bulb formation is influenced by the balance of stimulator and inhibitor hormones in plants. The presence of growth inhibitors is needed to focus energy on bulbs formation. Paclobutrazol is one of the growth retardants that can be used to regulate shoot growth and transfer photosynthetic energy to bulb formation (Ibrahim et al., 2015).

The paclobutrazol application is known to increase the activities of the sucrose transporter enzyme which plays a role in the translocation of sucrose from source to sink (Lee and Huang, 2013; Dewi and Darussalam, 2018). It decreases chlorophyllase activities because plants synthesize more cytokinins (Tsegaw et al., 2005). High content of chlorophyll and a slow degradation rate cause the photosynthetic activity of plants to run well, and the plants have a longer duration of the photosynthetic activity. The longer duration of the photosynthetic activity is expected to increase the yield on accumulated assimilates which will be translocated for bulbs formation. The increase in cytokinin synthesis is present due to the inhibition of gibberellin biosynthesis resulting in a secondary pathway. Cytokinins are known to be hormones that can support the bulbing process (Ni'mah et al., 2012). Research on several horticultural plants including peanut, mango, corn, carrot, potato and cassava showed that paclobutrazol can regulate shoot growth, biomass distribution, and finally increase yield (Senoo and Isoda, 2003; Nafeeset al., 2010; Lolaei et al., 2013; Wang et al., 2015; Mabvongwe et al., 2016; Panyapruek et al., 2016).

Attempts to increase the productivity of shallots in the context of fulfilling national consumption and seed needs have been made by the government. They include sustainable intensification programs, namely cultivation by GAP/SOP (the application of appropriate pesticides and fertilization), seed development, and also extensification with the use of marginal land and off-season cultivation. Increased productivity can also be done through the use of paclobutrazol. Based on the previous studies (Silva et al., 2003; Singh et al., 2005; Kishore et al., 2015), the use of paclobutrazol at the recommended/optimum doses and the right application time has neither affected soil microbial, nor dehydrogenase activity. Application at proper dose will maintain soil health and soil properties so that it will support sustainable farming systems.

However, such attempts to increase shallot productivity can be supported if seeds are available at all times. Therefore, the government encourages farmers to plant shallots using TSS instead of bulbs. Studies to increase the productivity of TSS are essential. This is also based on the fact that currently there is not much research on TSS that has been conducted. Research on the effectiveness of paclobutrazol in influencing growth in TSS has not yet been carried out. Also, previous research on the paclobutrazol application in some plants, particularly on the relationship between and influence of changes in physiological variables and growth of the yield, has not yet been discussed in detail. Therefore, it is necessary to deeply analyze the relationship between variables on the effectiveness of paclobutrazol in influencing plant growth activities to result in optimal TSS production. 


\section{MATERIALS AND METHOD}

The planting materials used in the study were such TSS cultivars as Tuk Tuk, Sanren and Lokananta. TSS was sown in soil blocks size of $2.5 \mathrm{~cm} \times 2.5 \mathrm{~cm} \times 2.5 \mathrm{~cm}$. TSS seeds were transplanted at 40 days after seedling. Test plot sized $1.4 \mathrm{~m} \mathrm{x} 1.6 \mathrm{~m}$ with a spacing of $10 \mathrm{~cm} \times 10$ $\mathrm{cm}$ and each planting hole had two plants. The planting was carried out from September to November 2017 in the experimental field of Universitas Gadjah Mada, Yogyakarta. The $3 \times 4$ factorial research was compiled based on Randomized Complete Block Design with three replications. The first factor involved the paclobutrazol concentration of $0,15,30$ and 45 $\mathrm{mg} \mathrm{L}^{-1}$, while the second factor included the TSS cultivars (Tuk Tuk, Sanren and Lokananta). The paclobutrazol used in the present study was a Patrol Brand $\left(250 \mathrm{~g} \mathrm{~L}^{-1}\right)$. Before being applied, the paclobutrazol was diluted to obtain a dose appropriate to the treatment with the principle of solution dilution using water. Paclobutrazol was applied at 20 day after planting (DAP) and 35 DAP by spraying $1,200 \mathrm{~mL}$ per plant-plot in the morning or approximately $5 \mathrm{~mL}$ per plant.

The physiological parameters including nitrate reductase activity (NRA) and the chlorophyll content was measured at 30 DAP and 70 DAP. The analysis of total chlorophyll content and NRA refers to the method developed by Bates et al. (1973). Leaf chlorophyll content was observed by mashing $1 \mathrm{~g}$ of fresh leaves and mixing with 20 $\mathrm{mL}$ of acetone $80 \%$. The filtrate was filtered and inserted in a cuvette to be tested using Spectronic 21D Milton Roy at $\lambda=645 \mu \mathrm{m}$ and $663 \mu \mathrm{m}$. The NRA was observed by cutting $0.2 \mathrm{~g}$ of fresh leaves $(1 \mathrm{~mm})$, inserting into a film tube containing $5 \mathrm{~mL}$ of phosphate buffer with $\mathrm{pH} 7.0$ before being incubated for 24 hours. After the 24-hour incubation, it was replaced by $5 \mathrm{~mL}$ of a new buffer and $0.1 \mathrm{~mL} \mathrm{M}$ of $\mathrm{NaNO}_{3}$ was added. The dye reagent solution $(0.2 \mathrm{~mL} 1 \% \mathrm{SA}$ in $3 \mathrm{~N} \mathrm{HCl}$ and $0.2 \mathrm{~mL} 0.02 \% \mathrm{NED}$ ) was put into the test tube. After 2-hour incubation, $0.1 \mathrm{~L}$ of the filtrate was then placed in the test tube left for minimum 15 minutes or after a pink color appeared, $2.5 \mathrm{~mL}$ of aquadest was then added. The homogeneous solution was transferred to the cuvette and measured for its absorbance at $\lambda=540 \mathrm{~nm}$.

The yield components included the total dry weight of the plants (TDW), bulb weight per planting hole, and productivity calculated at 70 DAP. The TDW was calculated by weighing all parts of the plant (roots, shoot, bulbs) after being dried using an oven at $80^{\circ} \mathrm{C}$ for 48 hours until the weight was constant. The bulb weight per planting hole was obtained by weighing the bulb weight of each planting hole when harvesting using a digital scale. The productivity calculation was carried out by making an observation plot area of $0.4 \mathrm{~m} \times 0.8$ $\mathrm{m}$ (32 planting holes) without border crops. The total bulb weight per plots area was weighed and the results were then converted to production per hectare. The calculation of plant growth analysis includes shoot biomass duration (SBD), plant growth regulator, leaf area index (LAI) and net assimilation rate (NAR) referring to Fageria et al. (2005).

The data were analyzed using Pearson correlation and regression to find out the closeness in the relationship between the observed variables and the effects between variables, and how paclobutrazol could improve the yield (Gomez and Gomez, 1995). Ms. Excel and the Statistical Analysis Software application (SAS version 9.4) were used in the data analysis (SAS Institute Inc., 2018).

\section{RESULTS AND DISCUSSION}

There was no interaction between the concentration of paclobutrazol application and TSS cultivars on all observed variables. The treatment of paclobutrazol had a significant effects on physiological and growth of shallots, but the effect of cultivars were no significant. At the paclobutrazol concentration of $15-30 \mathrm{mg} \mathrm{L}^{-1}$, the increase in LAI and SBD was present and it maintained the stability of leaf chlorophyll content until harvest age. At the paclobutrazol concentration of $45 \mathrm{mg} \mathrm{L}^{-1}$, the LAI value, SBD and leaf chlorophyll content tended to decrease when it was compared to plants applied with a paclobutrazol concentration of $15-30 \mathrm{mg} \mathrm{L}^{-1}$. The paclobutrazol application affected the LAI, SBD, chlorophyll content, NRA, root surface area (RSA), NAR, plant growth rate (PGR) and bulb weight per plant of the shallots, in which these variables had a positive correlation with shallots productivity (Table 1). The influence pattern of paclobutrazol was quadratic with a maximum peak point except in NRA variables which had a linear pattern (Figure 1). This indicated that the paclobutrazol application at optimum doses could maintain shoot biomass, leaf area, chlorophyll content, root and plant growth. 

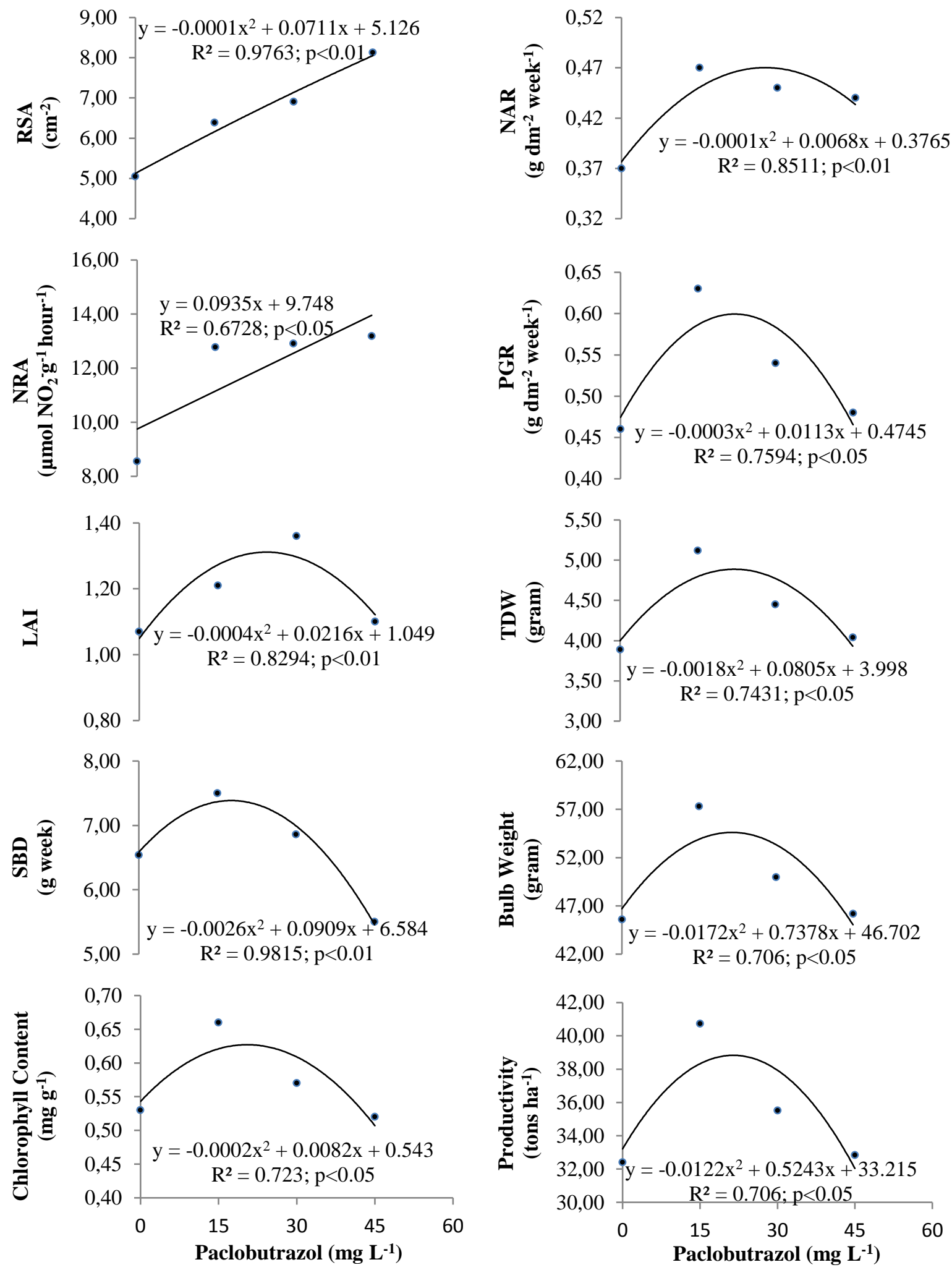

Figure 1. Regression of paclobutrazol concentration in RSA, NRA, LAI, SBD, chlorophyll content, NAR, PGR, TDW, bulb weight per planting hole and productivity 
Chlorophyll content had a close relationship with NRA (Fletcher and Gilley, 2000; Tsegaw, 2005). The NRA was very significantly positively associated with the leaf chlorophyll content of shallot plants $(\mathrm{r}=0.58, \mathrm{P}<0.01, \mathrm{n}=36)$. The NRA plays a role in the $\mathrm{N}$ assimilation process (Nouriyani et al., 2012). Many N elements were needed as tissue forming elements, supporting plant metabolism and chlorophyll forming elements (Sareer et al., 2016). The total leaf chlorophyll content of the plants applied with paclobutrazol with a concentration of $15-30 \mathrm{mg} \mathrm{L}^{-}$ ${ }^{1}$ was still high compared to plants without the application (Figure 1). This indicated that the paclobutrazol application could maintain the greenness of the leaves. Paclobutrazol could stimulate the synthesis of cytokininin plants. Cytokinin plays a role in increasing chloroplast differentiation, chlorophyll biosynthesis and preventing chlorophyll degradation (Banon et al., 2002; Sarkar et al., 2004; Still and Pill, 2004). Higher chlorophyll content and slower chlorophyll degradation will stimulate photosynthetic activities (Setia et al., 1995; Silva et al., 2013). Photosynthate will be used for several plant needs including growth so that the PGR shows an increase.

Table 1. Correlation matrix between physiological, growth parameters and yield of TSS

\begin{tabular}{|c|c|c|c|c|c|c|c|c|c|c|c|c|}
\hline Variabel & R1 & R2 & R3 & $\mathrm{R} 4$ & R5 & R6 & R7 & R8 & R9 & R10 & R11 & R12 \\
\hline $\begin{array}{l}\text { R1 } \\
\text { (NRA 30) }\end{array}$ & & & & & & & & & & & & \\
\hline $\begin{array}{l}\text { R2 } \\
\text { (NRA 70) } \\
\text { R3 }\end{array}$ & $-0.26^{\mathrm{ns}}$ & & & & & & & & & & & \\
\hline $\begin{array}{l}\text { (Chl 30) } \\
\text { R4 }\end{array}$ & $0.08^{\mathrm{ns}}$ & $0.20^{\mathrm{ns}}$ & & & & & & & & & & \\
\hline $\begin{array}{l}(\mathrm{Chl} 70) \\
\text { R5 }\end{array}$ & $0.58^{* *}$ & $0.20^{\mathrm{ns}}$ & $0.57^{* *}$ & & & & & & & & & \\
\hline $\begin{array}{l}\text { (TDW 70) } \\
\text { R6 }\end{array}$ & $0.22^{\mathrm{ns}}$ & $0.07^{\mathrm{ns}}$ & $0.36^{*}$ & $0.55^{* *}$ & & & & & & & & \\
\hline $\begin{array}{l}\text { (RSA 30) } \\
\text { R7 }\end{array}$ & $0.62^{* *}$ & $0.43^{* *}$ & $0.12^{\mathrm{ns}}$ & $-0.27^{\mathrm{ns}}$ & $0.50^{* *}$ & & & & & & & \\
\hline $\begin{array}{l}\text { (NAR) } \\
\text { R8 }\end{array}$ & $0.36^{*}$ & $0.36^{*}$ & $0.10^{\mathrm{ns}}$ & $0.52^{* *}$ & $0.55^{* *}$ & $-0.30^{\mathrm{ns}}$ & & & & & & \\
\hline $\begin{array}{l}\text { (PGR) } \\
\text { R9 }\end{array}$ & $0.46^{* *}$ & $0.02^{\mathrm{ns}}$ & $0.31^{\mathrm{ns}}$ & $0.57^{* *}$ & $0.99^{* *}$ & $0.46^{* *}$ & $0.36^{*}$ & & & & & \\
\hline $\begin{array}{l}\text { (LAI 30) } \\
\text { R10 }\end{array}$ & $0.06^{\mathrm{ns}}$ & $0.39^{*}$ & $0.14^{\text {ns }}$ & $0.04^{\mathrm{ns}}$ & $0.43^{* *}$ & $0.70^{* * *}$ & $-0.14^{\mathrm{ns}}$ & $0.34^{*}$ & & & & \\
\hline $\begin{array}{l}\text { (SBD) } \\
\text { R11 }\end{array}$ & $-0.19^{\mathrm{ns}}$ & $0.07^{\mathrm{ns}}$ & $0.43^{* *}$ & $0.52^{* *}$ & $0.72^{* *}$ & $0.35^{*}$ & $-0.24^{\mathrm{ns}}$ & $0.68^{* *}$ & $0.55^{* *}$ & & & \\
\hline $\begin{array}{l}(\mathrm{BWpH}) \\
\mathrm{R} 12\end{array}$ & $0.32^{\mathrm{ns}}$ & $0.31^{\text {ns }}$ & $0.17^{\mathrm{ns}}$ & $0.19^{\mathrm{ns}}$ & $0.72^{* *}$ & $0.53^{* *}$ & $-0.21^{\mathrm{ns}}$ & $0.67^{* *}$ & $0.55^{* *}$ & $0.65^{* *}$ & & \\
\hline (Productivity) & $0.40^{*}$ & $0.33^{*}$ & $0.17^{\mathrm{ns}}$ & $0.19^{\text {ns }}$ & $0.72^{* *}$ & $0.53^{* *}$ & -0.21 ns & $0.67^{* *}$ & $0.55^{* * *}$ & $0.65^{* *}$ & $1.00^{* *}$ & \\
\hline
\end{tabular}

Note : ${ }^{\text {ns }}=$ not significant; $*=$ significant; $* *=$ very significant; NRA; Chl (chlorophyll content); TDW; RSA; NAR; PGR; LAI; SBD; BWpH (Bulb weight per planting hole).

The biomass duration had a very significantly positive correlation with PGR $(\mathrm{r}=0.68, \mathrm{P}<0.01$, $\mathrm{n}=36$ ) (Table 1). The relationship between the SBD that was able to increase the PGR could be seen in the linear curve model (Figure 2). The longer the plant maintains the shoot biomass, the higher the accumulation of assimilates is formed. The formed assimilate is used as food reserves stored in economical storage organs and functions as plant metabolism so that it supports the plant growth. The results of the present study were in line with Diepenbrock (2000) study which showed that the paclobutrazol application was able to increase the number of productive pods as a result of biomass accumulation during the vegetative phase and the translocation of biomass to plant storage organs. The linear curve equation of the relationship between the SBD and the growth rate on shallots with the paclobutrazol application was $\mathrm{y}=0.0702 \mathrm{x}+0.0855 ; \mathrm{R}^{2}=$ 
0.9011, whereas that on shallots without the paclobutrazol application were $\mathrm{y}=0.0916 \mathrm{x}$ $0.1389 ; \mathrm{R}^{2}=0.824$. The linear curve of shallots with the paclobutrazol application lied above the linear curve of shallots without the paclobutrazol application. This shows that the shoot biomass of
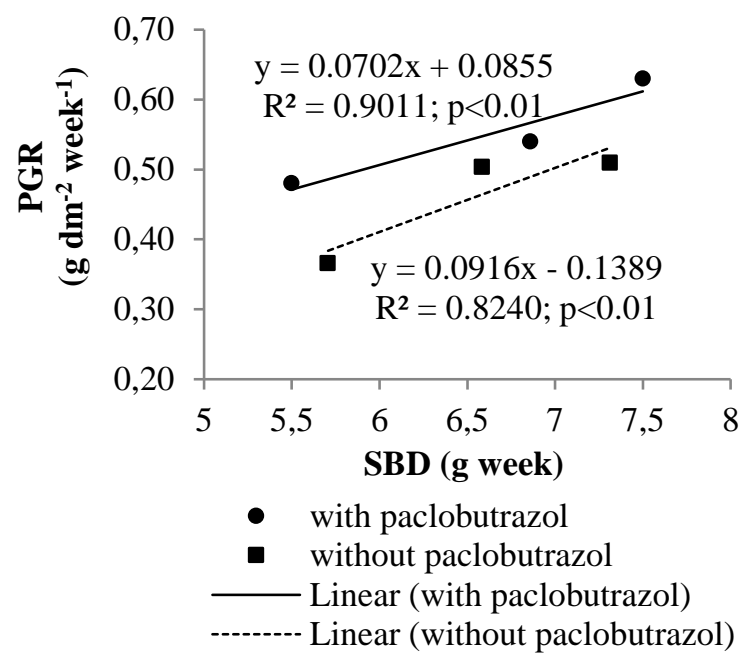

Figure 2. Regression between the SBD and the PGR of TSS plants

The paclobutrazol application resulted in an increase in LAI. In addition to chlorophyll content, the plants must be able to produce enough LAI quickly to absorb most of the light to obtain high yield so that the maximum dry weight production can be achieved. High LAI in plants illustrates the ability of plants to hold light radiation which plays a role in photosynthesis. Paclobutrazol increases chlorophyll content and specific leaf area so that it effectively improve photosynthesis (Tsegaw and Hammes, 2004; Tsegaw and Hammes, 2005). There was a quadratic regression relationship between LAI and NAR of shallot plants from seed multiplication. Figure 3 explains that LAI will affect the NAR of shallots. The quadratic equation of the relationship between LAI at 30 DAP and the growth rate on shallots with the paclobutrazol application was $y=-1.5618 x^{2}+3.8804 x-1.9387$; $\mathrm{R}^{2}=1$ and on shallots without the paclobutrazol application was $\mathrm{y}=-3.3247 \mathrm{x}^{2}+7.251 \mathrm{x}-3.5068$; $\mathrm{R}^{2}=1$. The quadratic curve of the shallots with the paclobutrazol application showed a higher peak point compared to the quadratic curve in shallots without the paclobutrazol application. This indicated that the paclobutrazol application increases the optimal LAI and the NAR of plants. shallots with the paclobutrazol application had a longer duration and higher PGR than that of shallots without the paclobutrazol application. Longer SBD will also have an impact on improvement leaf photosynthesis activity (Hunter and Proctor, 1992).

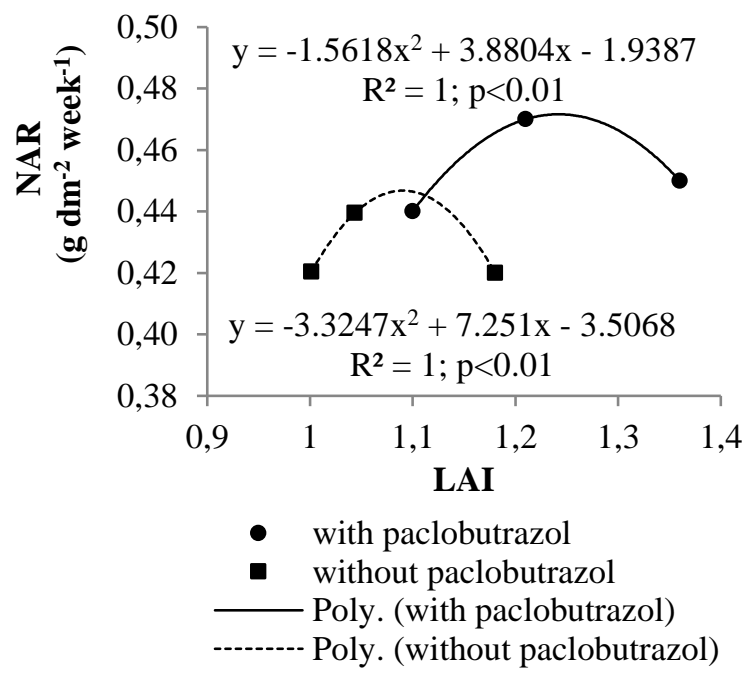

Figure 3. Regression between the LAI at 30 DAP and the NAR of TSS

The NAR describes the capacity of plants to form biomass so that the NAR will affect biomass accumulation and its distribution (Gomathinayagam et al., 2007).

Paclobutrazol showed a tendency to increase the NAR of shallots (Figure 1). The NAR can be used to describe the results of plant dry weight. The increase in the NAR elevated very significantly the plant dry weight $(\mathrm{r}=0.55, \mathrm{P}<$ $0.01, \mathrm{n}=36)$. The relationship between the NAR and the TDW of plants formed a linear pattern on shallots with the paclobtrazol application with $\mathrm{y}=$ $35.643 x-11.621 ; R^{2}=0.9973$ and on shallots without the paclobutrazol application with $\mathrm{y}=$ $29.917 x-8.9246 ; R^{2}=0.4802$ (Figure 4). The linear curve of shallots with the paclobutrazol application lied above the linear curve of shallots without the paclobutrazol application and had a higher slope. This showed that the paclobutrazol application could increase the NAR and TDW of shallots.

The leaf chlorophyll content of shallots was very significantly and positively correlated with the growth rate $(\mathrm{r}=0.57, \mathrm{P}<0.01, \mathrm{n}=36)$ (Table $1)$. The results of previous studies indicate that spraying paclobutrazol in plants was able to maintain the greenness of leaves so that they 
extend the duration of leaf photosynthesis. This condition will ultimately increase yield (Ghosh et al., 2010; Xuet al., 2013; Kuai et al., 2015). Chlorophyll supports the photosynthetic activities because it functions to capture sunlight at certain wavelengths and then will be used as energy in light reactions for hydrolysis processes and ATP and NADPH energy producers. The chlorophyll content of plants showed a linear relationship to the PGR (Figure 5). The linear curve equation on shallots with the paclobutrazol application was y $=1.0629 \mathrm{x}-0.070 ; \mathrm{R}^{2}=0.9976$ and on shallots without the paclobutrazol application was $\mathrm{y}=$ $1.2677 \mathrm{x}-0.214 ; \mathrm{R}^{2}=0.6392$. It showed that the paclobutrazol application was able to maintain a higher total leaf chlorophyll content thereby increasing the PGR.

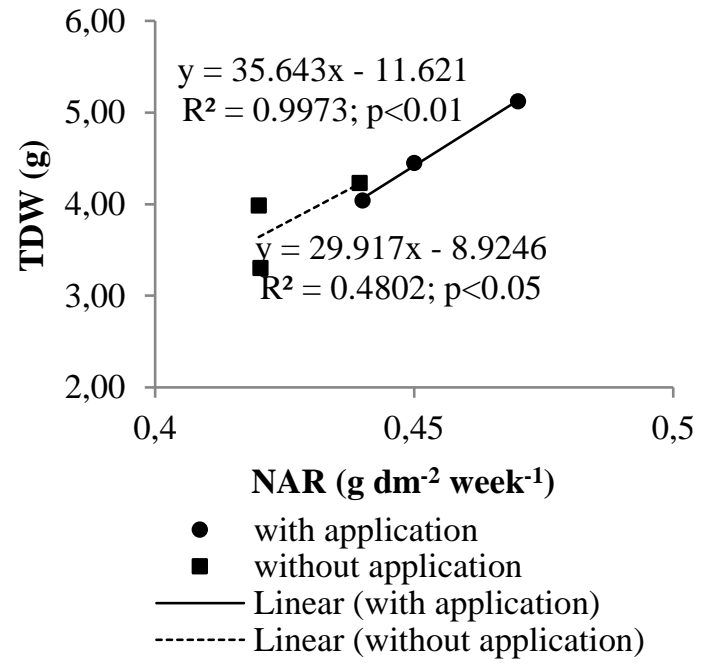

Figure 4. Regression between the NAR and the TDW of TSS plants

The PGR illustrates the ability of plants to produce dry material assimilated per unit area of land and time. The paclobutrazol application increased the PGR. The PGR was very significantly and positively correlated with bulb weight per planting hole $(\mathrm{r}=0.67, \mathrm{P}<0.01, \mathrm{n}=$ 36) (Table 1) and formed a linear relationship (Figure 6). The increase in the PGR would be followed by an increase in bulb weight per planting hole. The linear curve of the relationship between PGR and bulb weight per planting hole on shallots with the paclobutrazol application ( $\mathrm{y}=$ $\left.74.658 \mathrm{x}+10.078 ; \mathrm{R}^{2}=0.9953\right)$ was located at a higher position with a greater slope than that on shallots without the paclobutrazol application $(\mathrm{y}=$ $\left.23.006 \mathrm{x}+35.024 ; \mathrm{R}^{2}=0.8831\right)$. This indicated that the growth rate of shallots with the paclobutrazol application was higher than the growth rate of shallots without the paclobutrazol application and had an impact on increasing bulb weight per planting hole. In a previous study, an increase in NAR and PGR will spur an increase in biomass accumulation and finally lead to an increase in crop productivity (Barłóg and

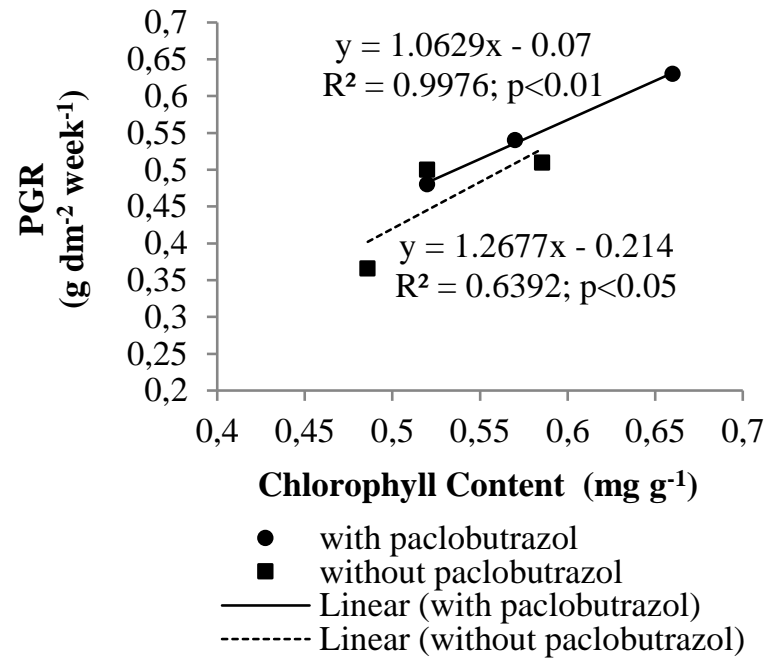

Figure 5. Regression between the chlorophyll content and the PGR of TSS plants

Grzebisz, 2004; Ruiz-Robleto and Villar, 2005; Sharma et al., 2007).

In addition to inhibiting gibberellin synthesis, paclobutrazol also increases the synthesis of ABA and cytokinin, so it will affect biomass accumulation and allocation of biomass distribution to plant organs. Accumulation of biomass in economical plant organs will indirectly increase crop productivity (Gopi et al., 2007; Gomes et al., 2011; Assuero et al., 2012; Song et al., 2018). Increasing bulb weight per planting hole will affect the productivity of shallots. The increase in bulb weight per planting hole was very significantly and positively correlated with an increase in shallot productivity $(\mathrm{r}=1, \mathrm{P}<0.01, \mathrm{n}$ =36). The bulb weight per planting hole had a linear regression relationship (Figure 7). The increase in bulb weight per planting hole would be followed by an increase in shallot productivity. The linear curve of the relationship between bulb weight per planting hole and the productivity of shallots with the paclobutrazol application was $y$ $=0.7111 \mathrm{x}+0.0018 ; \mathrm{R}^{2}=1$, while that of shallots without the paclobutrazol application was $\mathrm{y}=$ 
$0.6867 x+0.8788 ; R^{2}=0.9187$. It showed that shallots with the paclobutrazol application had higher bulb weight per planting hole compared to shallots without the paclobutrazol application.

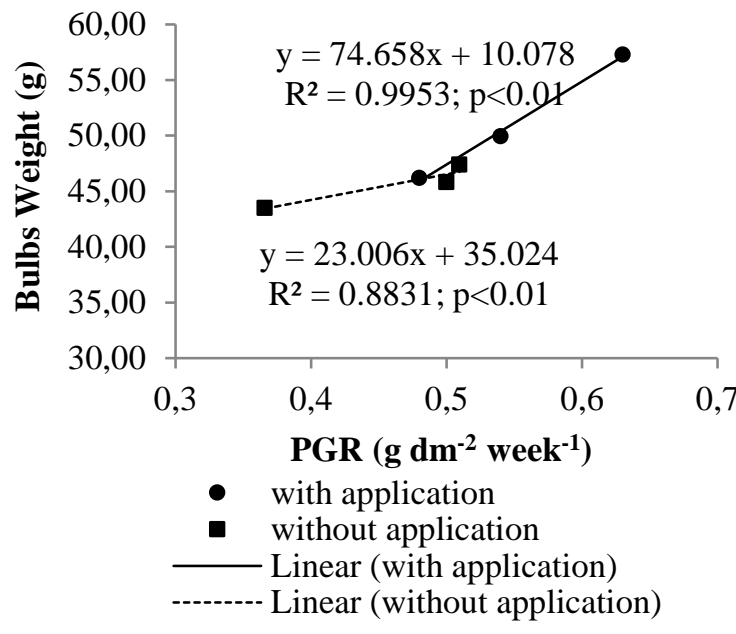

Figure 6. Regression between the PGR and the bulbs weight of TSS plants

The increase in bulb weight as a result of the paclobutrazol application was possible because paclobutrazol increases assimilate translocation from shoot to bulbs by activating enzymes that play a role in sucrose translocation (Kuai et al., 2014; Wu et al., 2018). Paclobutrazol can increase carbohydrate accumulation due to changes in morphogenesis, photosynthetic capacity and balance of phytohormones (Antonio et al., 2005; Zhen et al., 2012). Changes in endogenous hormonal balance will affect changes in assimilate partitions in plant organs, resulting in changes in assimilate distribution from source to sink until a balance occurs (Vu and Yelenosky, 1992; Huang et al., 1995). Changes in hormonal balance will also result in physiological and morphological changes in plants with the paclobutrazol application (Pal et al., 2016; Souza et al., 2016). Manipulation of these physiological activities will result in an increase in the photosynthesis rate and photosynthate translocation so that it will increase plant productivity (Nie et al., 2001; Yadav et al., 2005).

\section{CONCLUSIONS}

There was no interaction between the paclobutrazol concentration and the TSS cultivars on all observed variables. Paclobutrazol application influenced the TSS growth and yield, instead of cultivars. Paclobutrazol increased yield by improving the RSA and maintaining the SBD,

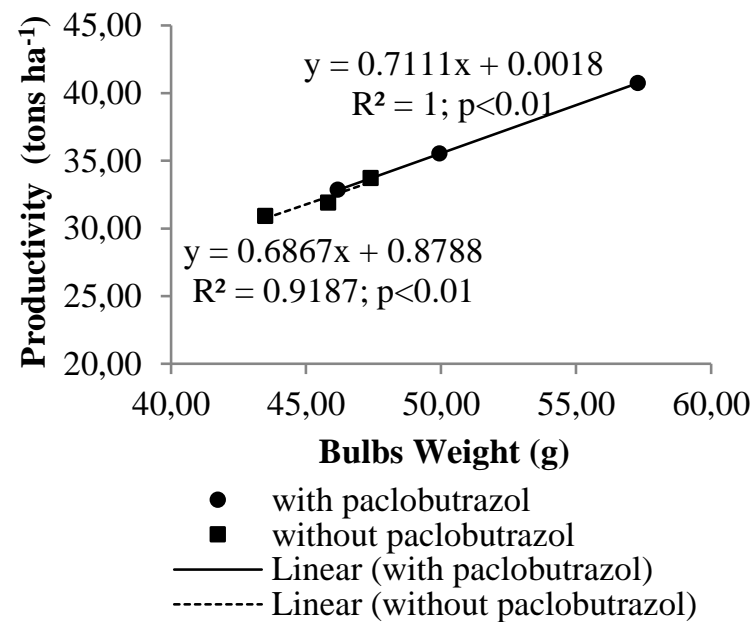

Figure 7. Regression between the bulbs weight and the productivity of TSS plants

the chlorophyll content and LAI which positively correlated with NAR and PGR. PGR had a positive correlation and a linear relationship with TDW and bulb weight per planting hole. The increase in PGR will be followed by an increase in bulb weight per planting hole and shallots productivity. The $15-30 \mathrm{mg} \mathrm{L}^{-1}$ paclobutrazol application was able to improve bulb yield.

\section{ACKNOWLEDGEMENT}

The authors would like to express gratitude to the Government of the Special Region of Yogyakarta and ACIAR for supporting the implementation of this research.

\section{REFERENCES}

Antonio, J., Moraes, P. J., Tinoco, S. de A., Barbosa, J. G., Finger, F.L., \& Cecon, P. R. (2005). Effects of paclobutrazol on growth and fruiting characteristics of "Pitanga" ornamental pepper. Acta Horticultura, 683, 333-336. doi: 10.17660/ActaHortic.2005.683. 41.

Assuero, S. G., Lorenzo, M., Ramirez, N. M. P., Velazquez, L. M., \& Tognetti, J. A. (2012). Tillering promotion by paclobutrazol in wheat and its relationship with plant carbohydrate status. New Zealand Journal of Agricultural Research, 55(4), 347-358. doi: 10.1080/ 00288233.2012 .706223 . 
Banon, S., Alberto, G., Emilio, A. C., Jose, A. F., \& Juan A. F. (2002). Growth, development and color response of potted Dianthus caryophyllusto paclobutrazol treatment. Scientia Horticulturae, 94, 371-377. doi: http://dx.doi.org/10.1016/S0304-4238(02)000 05-5.

Barłóg, P. \& Grzebisz, W. (2004). Effect of timing and nitrogen fertilizer application on Winter Oilseed Rape (Brassica napus L.). I. Nitrogen Uptake Dynamics and Fertilizer Efficiency. Journal of Agronomy and Crop Science, 190, 305-313. doi: http://dx.doi.org/ 10.1111/j.1439-037X.2004.00109.x.

Bates, L. S., Waldren, R. P., \& Teare, I. D. (1973). Rapid determination of free proline for water stress studies. Plant and Soils, 39, 205-207. doi: https://doi.org/10.1007/BF00018060.

BPS. (2018). Statistik Indonesia (Statistical yearbook of Indonesia) 2018. 1st ed. Edited by Subdirektorat Publikasi dan Kompilasi Statistik. Jakarta: Badan Pusat Statistik/BPSStatistics Indonesia. Online: https://www.bps. go.id/publication/2018/07/03/5a963c1ea9b0fe d6497d0845/statistik-indonesia-2018.html.

Dewi, K., \& Darussalam. (2018). Effect of paclobutrazol and cytokinin on growth and source-sink relationship during grain filling of black rice (Oryza sativa L. "Cempo Ireng'). Indian Journal of Plant Physiology, Springer India. doi: 10.1007/s40502-018-0397-1.

Diepenbrock, W. (2000). Yield analysis of winter oilseed rape (Brassica napus L.): a review. Field Crops Research, 67, 35-49. doi: http://dx.doi.org/10.1016/S0378-4290(00)000 $82-4$.

Fageria, N. K., Baligar, V. C., \& Clark, R. B. (2005). Physiology of crop production. Haworth: Food Product Press. Online: https://books.google.co.id/books?id=kX0Imc blXbAC\&printsec $=$ frontcover $\& \mathrm{hl}=\mathrm{id} \&$ source $=$ gbs_ViewAPI\&redir_esc $=\mathrm{y} \# \mathrm{v}=$ onepage $\& \mathrm{q}$ $\& \mathrm{f}=$ false.

Fletcher, R. A., \& Gilley, A. (2000). Triazoles as plant growth regulators and stress protectants. Horticultural Reviews, 24, 55-138. doi: http:// dx.doi.org/10.1002/9780470650776.ch3.

Ghosh, A., Chikara, J., Chaudhary, D. R., Prakash, A., Boricha, G., \& Zala, A. (2010).
Paclobutrazol arrests vegetative growth and unveils unexpressed yield potential of Jatropha curcas. Journal of Plant Growth Regulation, 29, 307-315. doi: 10.1007/s00 344-010-9137-0.

Gomathinayagam, M., Jaleel C. A., Lakshmanan G. M. A., \& Panneerselvam, R. (2007). Changes in carbohydrate metabolism by triazole growth regulators in cassava (Manihot esculenta Crantz); effects on tuber production and quality. Comptes Rendus Biologies, 330, 644-655. doi: 10.1016/j.crvi.2007.06.002.

Gomes, M., Castro, P. A., Mignone, C., \& Bertero, H. D. (2011). Can yield potential be increased by manipulation of reproductive partitioning in quinoa (Chenopodium quinoa)? Evidence from gibberellic acid synthesis inhibition using Paclobutrazol. Functional plant biology, 38, 420-430. Online: www. publish.csiro.au/journals/fpb.

Gomez, K. A., \& Gomez, A. A. (1995). Prosedur statistik untuk penelitian pertanian. The Second Edition. Jakarta: Universitas Indonesia Press.

Gopi, R., Jaleel, C. A., Sairam, R., Lakshmanan, G.M.A., Gomathinayagam, M., \& Panneerselvam, R. (2007). Differential effects of hexaconazole and paclobutrazol on biomass, electrolyte leakage, lipid peroxidation and antioxidant potential of Daucus carota L. Clolloids and surfaces $B$. Biointerfaces. 60, 180-186. doi: 10.1016/ j.colsurfb.2007.06.003.

Huang, W. D., Shen, T., Han, Z. H., \& Liu, S. (1995). Influence of paclobutrazol on photosynthesis rate and dry matter partitioning in the apple tree. Journal of Plant Nutrition, 18, 901-910. doi: 10.1080/01904169509364 947.

Hunter, D. M., \& Proctor, J. K. A. (1992). Paclobutrazol affects growth and fruit composition of potted grapevines. Horticultural Science, 27, 319-321. Retrieved from https://www.researchgate.net/publica tion/267948929_Paclobutrazol_Affects_Grow th_and_Fruit_Composition_of_Potted_Grape vines

Ibrahim, M., Nuraini, A., \& Widayat, D. (2015). Pengaruh sitokinin dan paklobutrazol terhadap 
pertumbuhan dan hasil benih kentang (Solanum tuberosum L.) G2 kultivar granola dengan sistem nutrient film technique. Jurnal Kultivase, 14(2), 36-41. Retrieved from http://jurnal.unpad.ac.id/kultivasi/article/view $/ 12073$

Kementerian Pertanian RI (The Ministry of Agriculture of the Republic of Indonesia). (2006). Deskripsi bawang merah varietas Tuk Tuk. Online: http://perundangan.pertanian. go.id/admin/file/SK-361-06.pdf.

Kementerian Pertanian RI (The Ministry of Agriculture of the Republic of Indonesia). (2013). Deskripsi bawang merah varietas Sanren. Online: http://varietas.net/dbvarietas/ deskripsi/4109.pdf.

Kementerian Pertanian RI (The Ministry of Agriculture of the Republic of Indonesia). (2017). Lampiran surat keputusan menteri pertanian Republik Indonesia. Online: http://varietas.net/dbvarietas/deskripsi/4704.p df.

Kishore, K., Singh, H. S., \& Kurian, R. M. (2015). Paclobutrazol use in perennial fruit crops and its residual effects: A review. Indian Journal of Agricultural Sciences, 85(7), 863-872. Retrieved from https://scinapse.io/papers/ 854504207

Kuai, J., Liu, Z., Wang, Y. H., Meng, Y. L., Chen, B. L., Zhao, W. Q., Zhou, Z. G., \& Oosterhuis, D. M. (2014).Waterlogging during flowering and boll forming stages affects sucrose metabolism in the leaves subtending the cotton boll and its relationship with boll weight. Plant Science, Elsevier Ireland Ltd. 223, 79-98. doi: 10.1016/j.plantsci.2014.03.010.

Kuai, J., Yang, Y., Sun, Y., Zhou, G. S., Zuo, Q. S., Wu, J. S., \& Ling, X. (2015). Paclobutrazol increases canola seed yield by enhancing lodging and pod shatter resistance in Brassica napus L. Field Crops Research, 180, 10-20. doi: 10.1016/j.fcr.2015.05.004.

Lee, S., \& Huang, W. (2013). Cytokinin, auxin, and abscisic acid affect sucrose metabolism conduce to de novo shoot organogenesis in rice (Oryza sativa L.) callus. Botanical Studies, 54(1). doi: 10.1186/1999-3110-54-5.

Lolaei, A., Mobasheri, S., Bemana, R., \& Teymori, N. (2013). Role of paclobutrazol on vegetative and sexual growth of plants. Journal of Agriculture and Crop Sciences, 5, 985-996. Retrieved from https://www. cabdirect.org/cabdirect/abstract/20133186838

Mabvongwe, O., Manenji, B. T., Gwazane, M., \& Chandiposha, M. (2016). The effect of paclobutrazol application time and variety on growth, yield, and quality of potato (Solanum tuberosum L.). Advances in Agriculture, doi: $10.1155 / 2016 / 1585463$.

Nafees, M., Faqeer, M., Ahmad, S., Khan, M. A., Jamil, M., \& Aslam, M. N. (2010). Paclobutrazol soil drenching suppresses vegetative growth, reduces malformation, and increases production in mango. International Journal of Fruit Science, 10(4), 431-440. doi: 10.1080/15538362.2010.530133.

Ni'mah, F., Ratnasari, E., \& Budipramana, L. S. (2012). Pengaruh pemberian berbagai kombinasi konsentrasi sukrosa dan kinetin terhadap induksi umbi mikro kentang (Solanum Tuberosum L.) kultivar granola kembang secara in-vitro. Jurnal Lentera Biologi, 1, 41-48. Retrieved from https:// jurnalmahasiswa.unesa.ac.id/index.php/lenter abio/article/view/193

Nie, L., Liu, H. X. \& Chen, L. G. (2001). Effects of uniconazole on growth, photosynthesis, and yield of longan. Acta Horticultura, 558, 289 292. doi: https://doi.org/10.17660/ActaHortic. 2001.558.46.

Nouriyani, H., Majidi, E., Seyyednejad, S. M., Siadat, S. A., \& Naderi, A. (2012). Effect of paclobutrazol under different levels of nitrogen on some physiological traits of two wheat cultivars (Triticum aestivum L.). World Applied Sciences Journal, 16(1), 1-6. Retrieved from https://pdfs.semanticscholar. org/e121/9a72228dae94be54aeb97d95b0e352 8dab89.pdf

Pal, S., Zhao, J., Khan, A., Yadav, N. S., Batushansky, A., Barak, S., Rewald, B., Fait, A., Lazarovitch, N., \& Rachmilevitch, S. (2016). Paclobutrazol induces tolerance in tomato to deficit irrigation through diversified effects on plant morphology, physiology, and metabolism. Scientific reports, Nature Publishing Group, 6(39321), 1-13. doi: 10.1038/srep39321. 
Pangestuti, R. \& Sulistyaningsih, E. (2011). Potensi Penggunaan True Seed Shallot (TSS) Sebagai Sumber Benih di Indonesia. In Prosiding Seminaloka Nasional "Dukungan Agro-Inovasi untuk Pemberdayaan Petani". Semarang, 258-266. Retrieved from https://www.researchgate.net/publication/308 120605_POTENSI_PENGGUNAAN_TRUE SEED SHALLOT TSS SEBAGAI_SUMB ER_BENIH_BAWANG_MERAH_DI_INDO NESIA

Panyapruek, S., Sinsiri, W., Sinsiri, N., Arimatsu, P., \& Polthanee, A. (2016). Effect of paclobutrazol growth regulator on tuber production and starch quality of cassava (Manihot esculenta Crantz). Asian Journal of Plant Sciences, 15(1), 1-7. doi: 10.3923/ajps. 2016.1.7.

Pardjo, Y.V., Sulandjari \& Sunu, P. (2012). Efektivitas jenis polinator dan asupan hara terhadap hasil biji dan umbi bawang merah (Alium cepa L). Caraka Tani: Journal of sustainable agriculture, 27(2), 174-181. https://doi.org/10.20961/carakatani.v27i2.142 70

Ruiz-Robleto, J., \& Villar, R. (2005). Relative growth rate and biomass allocation in ten woody species with different leaf longevity using Phylogenetic Independent Contrasts (PICs). Plant Biology. 7, 484-494. doi: 10.1055/s-2005-865905.

Sareer, O., Bernstein, N., Ahmad, S., \& Umar, S. (2016). Genetic, developmental and temporal variability in nitrate accumulation and nitrate reductase activity in medicinal herb Andrographis paniculata. Pedosphere: An International Journal, 26(6), 839-847. doi: 10.1016/S1002-0160(15)60089-3.

Sarkar, S., Michel, R., Perras, S., Duane, E., Ruichuan, Z., \& Richard, P. (2004). Relationship between gibberellins, height, and stress tolerance in barley (Hordeum vulgare L.) seedlings. Plant Growth, 42, 125-135. doi: http://dx.doi.org/10.1023/B:GROW.00000174 92.56792.64.

SAS Institute Inc. (2018). SAS 9.4 OLAP Server: User's Guide. Fifth Edition. Cary, NC, USA: SAS Institute Inc.

Senoo, S., \& Isoda, A. (2003). Effects of paclobutrazol on dry matter distribution and yield in peanut. Plant Production Science, 1(6), 90-94. doi: 10.1626/pps.6.90.

Setia, R. C., Bhathal, G., \& Setia, N. (1995). Influence of paclobutrazol on growth and yield of Brassica carinata A. Br. Plant Growth Regulation, 16, 121-127. doi: 10.1007/ BF00029532.

Sharma, R. K., Agrawal, M., \& Agrawal, S. B. (2007). Interactive effects of cadmium and zinc on carrots: growth and biomass accumulation. Journal of Plant Nutrition, 31, 19-34. doi: 10.1080/01904160701741727.

Silva, C. M. M., Vieira, R. F., \& Nicolella, G. (2003). Paclobutrazol effects on soil microorganisms. Applied Soil Ecology, 22(1), 79-86. doi: 10.1016/S0929-1393(02)00110-5.

Silva, M. D. A., Jifon, J. L., Santos, C. M., Jadoski, C. J., \& Silva, J.A.G.(2013). Photosynthetic capacity and water use efficiency in sugarcane genotypes subject to water deficit during early growth phase. Brazilian Archives of Biology and Technology, 56(5), 735-748. doi: 10.1590/S1516-8913201 3000500004 .

Singh, V. K., Garg, N., \& Bhriguvanshi, S. R. (2005). Effect of paclobutrazol doses on nutritional and microbiological properties of mango (Mangifera indica) orchard soils. Indian Journal of Agricultural Sciences, 75(11), 738-739. Retrieved from https:// eurekamag.com/research/004/421/004421235. php

Song, C., Zhu, G., Jiao, X., \& Zhou, G. (2018). Effects of paclobutrazol on dry matter accumulation and grain filling of castor bean. American Journal of Biological and Environmental Statistics, 4(3), 83-90. doi: 10.11648/j.ajbes.20180403.11.

Souza, M. A., Mesquita, A. C., Simoes, W. L., Ferreira, K. M., \& Araujo, E. F. J. (2016). Physiological and biochemical characterization of mango tree with paclobutrazol application via irrigation. Pesquisa Agropecuária Tropical, 46, 442449. doi: 10.1590/1983-40632016v4642829.

Still, J. R., \& Pill, W. G. (2004). Growth and stress tolerance of tomato seedlings (Lycopersicon esculentum Mill) in response to seed treatment 
with paclobutrazol. The Journal of Horticultural Science and Biotechnology, 79(2), 197-203. doi: 10.1080/14620316.2004. 11511748 .

Tsegaw, T. (2005). Response of Potato to Paclobutrazol and Manipulation of Reproductive Growth (Doctoral Thesis). Horticultural Science Department of Plant Production and Soil Science. The University of Pretoria. Retrieved from https://repository.up. ac.za/handle/2263/27243

Tsegaw, T., \& Hammes, P. S. (2004). Response of potato grown under non-inductive condition to paclobutrazol: shoot growth, chlorophyll content, net photosynthesis, assimilate partitioning, tuber yield, quality, and dormancy. Plant Growth Regulation, 43, $227-$ 236. doi: http://dx.doi.org/10.1023/B:GROW. 0000045992.98746.8d.

Tsegaw, T., \& Hammes, P. S. (2005). Growth and biomass production in potato grown in the hot tropics as influenced by paclobutrazol. Plant Growth Regulation, 45, 37-46. doi: 10.1007/ s10725-004-6443-1.

Tsegaw, T., Hammes, S., \& Robbertse, J. (2005). Paclobutrazol-induced leaf, stem, and root anatomical modifications in potato. HortScience, 40(5), 1343-1346. https:// doi.org/10.21273/HORTSCI.40.5.1343

Vu, J. C. V., \& Yelenosky, G. (1992). Growth and photosynthesis of sweet orange plants treated with paclobutrazol. Journal of Plant Growth Regulation, 11, 85-89. doi: 10.1007/bf0019 8019.

Wang, G., Que, F., Xu, Z., Wang, F., \& Xiong, A. (2015). Exogenous gibberellin altered morphology, anatomic and transcriptional regulatory networks of hormones in carrot root and shoot. BMC Plant Biology, 15(290), 1-12. doi: 10.1186/s12870-015-0679-y.

Widodo, W. D., Poerwanto, R., Sumarni, N., \& Sopha, G. A. (2011). Teknologi True Shallot Seed (TSS) sebagai bahan tanam untuk meningkatkan produktivitas bawang merah. In Prosiding Hasil-Hasil Penelitian IPB 2011. Retrieved from https://repository.ipb.ac.id/ handle/123456789/72245

Wu, Y., Sun, M. Y., Zhang, J., Zhang, L., Ren, Z., Min, R., Wang, X., \& Xia, Y. (2018). Differential effects of paclobutrazol on the bulblet growth of oriental lily cultured in vitro: growth behavior, carbohydrate metabolism, and antioxidant capacity. Journal of Plant Growth Regulation, 1-14. doi: 10.1007/ s00344-018-9844-5.

Xu, G., Luo, R., \& Yao, Y. (2013). Paclobutrazol improved the reproductive growth and the quality of seed oil of Jatropha curcas. Journal of Plant Growth Regulation, 32(4), 875-883. doi: 10.1007/s00344-013-9353-5.

Yadav, R. K., Rai, N., Yadav, D. S., \& Asati, B. S. (2005). Use of paclobutrazol in horticultural crops: A review. Agricultural Reviews, 26(2), 124-132. Retrieved from https://www. arccjournals.com/journal/agriculturalreviews/ARCC4212

Zheng, R., Wu, Y., \& Xia, Y. (2012). Chlorocholine chloride and paclobutrazol treatments promote carbohydrate accumulation in bulbs of Lilium Oriental hybrids "Sorbonne". Journal of Zhejiang University SCIENCE B, 13(2), 136-144. doi: 10.1631/jzus.b1000425. 